\title{
ANALISIS FAKTOR CAPAIAN REALISASI PENERIMAAN RETRIBUSI JASA ANGKUTAN SUNGAI DAN PENYEBERANGAN PADA DINAS PERHUBUNGAN KOTA PALEMBANG
}

\author{
Darma Yanti \\ Rosalina Ghozali \\ Universitas Muhammadiyah Palembang \\ Alamat Korepondensi: darmaaisha@gmail.com
}

\begin{abstract}
River and crossing service levies are transport activities using ships carried out in the river, and crossings to transport passengers, goods and or animals organized by river and crossing companies. The factor of not achieving the realization of the revenue of river transportation and crossing retribution services in the Palembang City Transportation Agency, setting unrealistic targets is constrained by a lack of legal basis so as to achieve the desired target cannot be achieved and limited authority for officers who withdraw fees due to regulatory regulations Number 35 of 2017 concerning escorts that are still in conflict with the Laws Regulations, Ministerial Regulations, Government Regulations, and Regional Regulations. The collection of retribution is also experiencing leakage or breakthrough due to the effectiveness of the imposition of sanctions and the lack of facilities and infrastructure in the field. The service is not yet prime due to limited human resources or field implementation officers. The levies collection officer is not unwilling to provide services and human resources, but also because of conflicting rules that prevent officers from carrying out a complete withdrawal. Officers move with the rules set by the City Government so that their authority is limited.
\end{abstract}

\section{KATA KUNCI:}

Retribusi Jasa Angkutan Sungai dan Penyeberangan

\section{ABSTRAK}

Retribusi jasa angkutan sungai dan penyeberangan merupakan kegiatan angkutan dengan menggunakan kapal yang dilakukan di sungai dan penyeberangan untuk mengangkut penumpang, barang, dan/atau hewan yang diselenggarakan oleh perusahaan angkutan sungai dan penyeberangan. Faktor tidak tercapainya realisasi penerimaan retribusi jasa angkutan sungai dan penyeberangan di Dinas Perhubungan Kota Palembang, penentuan target yang belum realistis terkendala di dasar hukum yang kurang kuat sehingga untuk mencapai target yang diinginkan tidak dapat tercapai dan kewenangan yang terbatas untuk petugas yang melakukan penarikan retribusi dikarenakan peraturan Perwali Nomor 35 Tahun 2017 Tentang Pengawalan yang masih bertentangan dengan Peraturan Undang-undang, Peraturan Menteri, Peraturan Pemerintah, dan Peraturan Daerah. Pemungutan retribusinya juga mengalami kebocoran atau kelolosan karena belum efektifitasnya pemberlakuan sanksi dan kurangnya sarana dan prasarana dilapangan. Belum primanya layanan karena terbatasnya sumber daya manusia atau petugas pelaksanaan dilapangan. Petugas pemungutan retribusi bukan tidak mau memberikan pelayanan dan sumber daya manusia juga tetapi karena aturan yang bertentangan sehingga membuat petugas tidak bisa menjalankan penarikan secara menyeluruh. Petugas bergerak dengan aturan yang telah ditetapkan oleh Pemerintah Kota sehingga kewenangannya terbatas.

\section{KLASIFIKASI JEL:}

H71, R48

\section{CARA MENGUTIP:}

Yanti, D. \& Ghozali, R. (2020). Analisis faktor capaian realisasi penerimaan retribusi jasa angkutan sungai dan penyeberangan pada dinas perhubungan kota palembang. Indonesian Treasury Review: Jurnal Perbendaharaan, Keuangan Negara dan Kebijakan Publik, 5(2), 121-129. 


\section{PENDAHULUAN}

Undang-Undang Nomor 32 tahun 2004 menyatakan bahwa otonomi daerah adalah kewenangan daerah untuk mengatur dan mengurus kepentingan masyarakat setempat menurut prakarsa sendiri berdasarkan aspirasi masyarakat dalam ikatan Negara Kesatuan Republik Indonesia. Menurut Sujarweni (2015, hal. 230), dua hal yang menjadi prinsip otonomi daerah ini adalah kewenangan dan partisipasi (aspirasi) masyarakat dalam pelaksanaan pembangunan daerah. Pada prinsipnya hakikat otonomi daerah adalah mempunyai sumber keuangan sendiri, dapat mengelola dan menggunakannya untuk melaksanakan tugas-tugas otonomi serta mempunyai anggaran belanja yang ditetapkan sendiri (Pekei, 2016, hal. 16).

Pelaksanaan otonomi daerah pemerintah daerah diberikan kewenangan yang luas dalam menyelenggarakan semua urusan pemerintah mulai dari perencanaan, pelaksanaan, pengawasan, pengendalian, pengelolaan, dan penggalian potensi sumber daya yang dimiliki guna memenuhi kebutuhan daerah dan pelayanan masyarakat. Salah satu yang menjadi modal dalam pelaksanaan otonomi daerah adalah Pendapatan Asli Daerah (PAD) (Yuliastuti \& Dewi, 2017, hal. 92).

Retribusi jasa angkutan sungai dan penyeberangan adalah kegiatan angkutan dengan menggunakan kapal yang dilakukan di sungai, dan penyeberangan untuk mengangkut penumpang, barang dan atau hewan yang diselenggarakan oleh perusahaan angkutan sungai dan penyeberangan. Faktor-faktor tidak tercapainya realisasi penerimaan retribusi daerah yaitu penerimaan yang belum realistis yang dilihat dari sistem penentuan target yang didasarkan historis dan belum dimilikinya database atau data dasar mengenai sumber penerimaan. Tingginya tingkat kebocoran atau kelolosan dikarenakan belum efektifitasnya pemberlakuan sanksi dan kurangnya sarana dan prasarana di lapangan. Kurang primanya layanan karena terbatasnya sumber daya manusia atau tugas pelaksanaan di lapangan, serta adanya birokrasi dalam layanan pemungutan pajak retribusi (Susilo \& Halim, 2002, hal. 49).

Penentuan target yang belum terealistis dikarenakan terjadi fluktuasi antara target penerimaan dengan presentase yang didapatkan karena tidak berjalannya target penerimaan yang dianggarkan. Penerimaan target yang belum realistis dikarenakan adanya permasalahan pada retribusi jasa angkutan sungai dan penyeberangan yaitu jasa rambu dan wajib pengawalan yang belum dapat diterapkan sepenuhnya oleh pemerintah dikarenakan dasar hukum yang kurang kuat dan kewenangan yang terbatas sehingga menyebabkan sarana dan prasarana di lapangan yaitu fasilitas di perairan tidak memadai.
Penelitian yang dilakukan (Mega \& Elim, 2016, hal. 895) menyatakan bahwa hasil penelitiannya menunjukkan bahwa tingkat efektivitas untuk restribusi daerah selama tahun 2011-2015 masuk dalam kategori cukup efektif. Kontribusi restribusi daerah PAD Provinsi Sulawesi Utara (Sulut) dari tahun 2011-2015 berkontribusi sedang tetapi rasio kontribusinya cenderung naik untuk setiap tahunnya hanya pada tahun 2015 mengalami penurunan.

Hasil analisis dari penelitian yang dilakukan (Sri \& Kasasih, 2017, hal. 106) dapat disimpulkan bahwa retribusi pasar berkontribusi terhadap pendapatan daerah. Efektivitas realisasi retribusi pasar pada tahun 2011 dianggap tidak efektif. Tingkat efektivitas 2012-2013 dianggap sudah efektif. Namun, pada 2014-2015 dianggap tidak efektif. Sedangkan penelitian yang dilakukan oleh (Yuliastuti \& Dewi, 2017, hal. 100) berdasarkan hasil analisis dapat disimpulkan bahwa rata-rata efektifitas Retribusi Kota Denpasar tahun 20112015 adalah termasuk pada kriteria sangat efektif dan kontribusi rata-rata Retribusi Pendapatan Daerah Kota Denpasar pada tahun 2011-2015 kriteria adalah sangat buruk.

Dinas perhubungan (Dishub) Kota Palembang memiliki tugas untuk menyelenggarakan urusan kebijakan perhubungan atau transportasi untuk daerah Kota Palembang. Fungsi dari dinas perhubungan adalah merumuskan kebijakan bidang perhubungan dalam wilayah kerjanya, kebijakan teknis bidang perhubungan, penyelenggaraan administrasi termasuk perizinan angkutan pembangunan, evaluasi, dan laporan terkait bidang perhubungan.

Berikut target penerimaan dan realisasi penerimaan Retribusi Jasa Angkutan Sungai dan Penyeberangan Kota Palembang untuk periode tahun 2015-2018 disajikan pada tabel berikut ini:

Tabel 1. Data Penerimaan Retribusi Jasa Angkutan Sungai dan Penyeberangan

\begin{tabular}{|c|r|r|r|}
\hline Tahun & $\begin{array}{c}\text { Target } \\
\text { Penerimaan(Rp) }\end{array}$ & $\begin{array}{c}\text { Realisasi } \\
\text { Penerimaan(Rp) }\end{array}$ & Persentase \\
\hline 2015 & 2.000 .000 .000 & 2.508 .803 .948 & $125,44 \%$ \\
\hline 2016 & 2.000 .000 .000 & 2.853 .809 .800 & $142,69 \%$ \\
\hline 2017 & 2.000 .000 .000 & 3.469 .803 .840 & $173,49 \%$ \\
\hline 2018 & 37.685 .248 .010 & 4.266 .115 .259 & $11,32 \%$ \\
\hline
\end{tabular}

Sumber: Badan Pengelolaan Keuangan Dan Aset

Daerah, 2018

Berdasarkan tabel di atas menunjukkan bahwa retribusi jasa angkutan sungai dan penyeberangan belum mencapai target penerimaan yaitu $11,32 \%$, sedangkan tahun sebelumnya presentase mencapai target dan realisasinya adalah rata-rata lebih dari $100 \%$. Tingkat target penerimaan jasa angkutan sungai dan penyeberangan mengalami fluktuasi dengan target yang dianggarkan. Kondisi tersebut disebabkan beberapa faktor, antara lain penetapan 
target belum realistis, masih tingginya tingkat kebocoran atau kelolosan terjadi karena setiap setoran hasil pemungutan tidak mencapai target yang ditetapkan, kurangnya pemberlakuan sanksi dan kurangnya sarana dan prasarana yang dimiliki. Kurang primanya layanan dikarenakan terbatasnya sumber daya manusia atau petugas pelaksanaan di lapangan. Tingkat pelayanan petugas sudah maksimal tetapi karena dasar hukum yang kurang kuat dan kewenangan yang terbatas sehingga menyebabkan hambatan dalam pemungutan retribusi tersebut.

Berdasarkan uraian di atas, maka tujuan penelitian ini adalah untuk mengetahui faktor apa saja yang menyebabkan tidak tercapainya realisasi penerimaan retribusi jasa angkutan sungai dan penyeberangan pada Dishub Kota Palembang. Penelitian ini diharapkan dapat menjadi bahan referensi bagi dinas penghubung dan bagi pemerintah sebagai bahan acuan atau referensi untuk meningkatkan penerimaan retribusi daerah.

\section{LANDASAN TEORI}

\subsection{Retribusi Daerah}

Menurut Windhu (2018, hal. 185) restribusi daerah adalah iuran yang dibayarkan oleh rakyat kepada daerah yang dapat dipaksakan yang mendapat prestasi kembalinya secara langsung. Menurut Yoyo (2017, hal. 108) restribusi daerah adalah pungutan daerah sebagai pembayaran atas jasa atau pemberian izin tertentu yang khusus disediakan dan/atau diberikan oleh pemerintah daerah untuk kepentingan orang pribadi atau badan. Menurut Siahaan (2016, hal. 616) retribusi daerah adalah pungutan daerah sebagai pembayaran atas jasa atau pemberian izin tertentu yang khusus disediakan atau diberikan oleh pemerintah daerah untuk kepentingan orang pribadi atau badan.

Berdasarkan beberapa pengertian dapat disimpulkan bahwa restribusi daerah adalah daerah provinsi, kabupaten/kota diberi peluang dalam menggali potensi sumber-sumber keuangannya dengan menetapkan jenis retribusi selain yang telah ditetapkan, sepanjang memenuhi kriteria yang telah ditetapkan dan sesuai dengan aspirasi masyarakat.

\subsection{Perhitungan Retribusi Daerah}

Menurut Siahaan (2016, hal. 638-642) besarnya retribusi yang terutang oleh orang pribadi atau badan yang menggunakan jasa atau perizinan tertentu dihitung dengan cara mengalikan tingkat penggunaan jasa dengan tarif retribusi.

Menurut Siahaan (2016, hal. 642) besarnya retribusi daerah yang harus dibayar oleh orang pribadi atau badan yang menggunakan jasa yang bersangkutan dihitung dari perkalian antara tarif retribusi dan tingkat penggunaan jasa dengan rumus berikut ini:

Retribusi terutang $=$ Tarif retribusi $\mathrm{x}$ Tingkat penggunaan jasa

\subsection{Faktor-faktor Penyebab Tidak Tercapainya Realisasi Penerimaan Retribusi Daerah}

Menurut Susilo dan Halim (2002, hal. 49) dalam kajian tentang keuangan daerah pemerintah sumber-sumber keuangan daerah yang dapat mempengaruhi pendapatan asli daerah yang dapat diterima oleh pemerintah daerah adalah belum optimalnya pajak dan retribusi daerah di mana penyebabnya karena faktor:

1. Target penerimaan belum realistis, ini bisa dilihat dari:

a. Sistem penentuan target yang didasarkan pada historis.

b. Belum dimilikinya database atau data dasar mengenai sumber penerimaan.

2. Masih tingginya tingkat kebocoran atau kelolosan, ini dikarenakan:

a. Belum efektifitasnya pembelakuan sanksi.

b. Kurangnya sarana dan prasarana untuk operasional di lapangan.

3. Belum primanya layanan karena terbatasnya sumber daya manusia atau tugas pelaksanaan di lapangan, serta adanya birokrasi dalam layanan pemungutan pajak retribusi.

\subsection{Pemungutan Retribusi Daerah}

Menurut Undang-Undang Nomor 18 Tahun 1997 pasal 26 pemungutan retribusi tidak dapat diborongkan. Artinya seluruh proses kegiatan pemungutan retribusi tidak dapat diserahkan kepada pihak ketiga. Retribusi dipungut dengan menggunakan Surat Ketetapan Retribusi Daerah (SKRD) atau dokumen lain yang dipersamakan. SKRD adalah surat ketetapan retribusi yang menentukan besarnya pokok retribusi.

Retribusi dipungut dengan menggunakan Surat Ketetapan Retribusi Daerah (SKRD) atau dokumen lain yang dipersamakan. SKRD merupakan surat ketetapan retribusi yang menentukan besarnya pokok retribusi. Dokumen lain yang dipersamakan antara lain, berupa karcis, kupon, dan kartu langganan. Dalam hal wajib retribusi tertentu tidak membayar retribusi tepat pada waktunya atau kurang membayar, maka kepadanya dikenakan sanksi administrasi berupa bunga sebesar dua persen setiap bulan dari retribusi terutang yang tidak atau kurang dibayar dan ditagih dengan menggunakan Surat Tagihan Retribusi Daerah (STRD).

STRD adalah surat untuk melakukan tagihan retribusi dan/atau sanksi administrasi berupa bunga dan/atau denda. Tata cara pemungutan retribusi ditetapkan dengan peraturan kepala daerah menurut Undang-Undang No 28 Tahun 2009 pada pasal 161 menetapkan bahwa pemanfaatan masing-masing jenis retribusi 
diutamakan untuk mendanai kegiatan yang berkaitan langsung dengan penyelenggaraan pelayanan yang bersangkutan.

\section{METODE PENELITIAN}

Penelitian ini adalah penelitian deskriptif yaitu menjelaskan faktor penyebab tidak tercapainya realisasi penerimaan retribusi jasa angkutan sungai dan penyeberangan pada Dinshub Kota Palembang periode tahun 2015-2018 dengan membahas penerimaan target retribusi yang tidak realistis, masih tingginya tingkat kebocoran, dan belum primanya tingkat layanan dan pengawasan

Data yang digunakan dalam penelitian ini adalah data primer dan sekunder. Data primer yang digunakan yaitu data keuangan yang didapat langsung dengan melalui wawancara. Data sekunder yang digunakan yaitu melalui kutipankutipan buku dan data yang bersumber dari internet. Data berupa laporan target dan realisasi penerimaan retribusi jasa angkutan sungai dan penyeberangan tahun 2015-2018.

Instrumen pengumpulan data yang digunakan dalam penelitian ini adalah wawancara dan dokumentasi. Wawancara dan dokumentasi dengan memakai suatu pedoman wawancara yang berisi daftar pertanyaan sesuai tujuan yang ingin dicapai dan mendapatkan data berupa laporan keuangan realisasi yang diambil pada tahun 20152018 pada Dishub Kota Palembang.

Analisis data yang digunakan dalam penelitian ini adalah analisis kualitatif deskriptif, yang digunakan untuk menguraikan dan menjelaskan realisasi penerimaan retribusi jasa angkutan sungai dan penyeberangan pada dinas perhubungan kota Palembang berasal dari dokumentasi dan wawancara yang disajikan untuk menjawab permasalahan penelitian teknik analisis yang digunakan dalam penelitian ini adalah teknik analisis deskriptif kualitatif yang memusatkan perhatian pada sesuatu yang ada dengan mengumpulkan, mencatat, menyusun, mengklasifikasikan, dan menganalisis atau menyajikan data yang diperoleh dalam bentuk tabel dan akhirnya diambil dalam bentuk kesimpulan.

\section{HASIL PENELITIAN}

4.1. Analisis Faktor Tidak Tercapainya Realisasi Penerimaan Retribusi Jasa Angkutan Sungai Dan Penyeberangan Pada Dinas Perhubungan Kota Palembang

Berdasarkan hasil penelitian analisis faktor tidak tercapainya realisasi penerimaan retribusi jasa angkutan sungai dan penyeberangan pada Dishub Kota Palembang, maka penulis dapat menganalisis faktor tidak tercapainya realisasi penerimaan retribusi jasa angkutan dan penyeberangan. Adapun faktor tidak tercapainya realisasi penerimaan retribusi jasa angkutan sungai dan penyeberangan pada dinas perhubungan Kota Palembang adalah sebagai berikut:

4.1.1. Penerimaan Target Yang Belum Realistis

a. Analisis sistem penentuan target yang didasarkan pada historis

Berdasarkan dari fenomena masalah maka data penerimaan target retribusi jasa angkutan sungai dan penyeberangan tiap tahun meningkat dengan persentase yang mencapai target tetapi di tahun 2018 target mengalami fluktuasi. Hal ini dapat dilihat dengan tabel dibawah ini:

Tabel 2. Data Penerimaan Retribusi Jasa Angkutan Sungai dan Penyeberangan Kota Palembang

\begin{tabular}{|c|r|c|c|}
\hline Tahun & $\begin{array}{c}\text { Target } \\
\text { Penerimaan } \\
\text { (Rp) }\end{array}$ & $\begin{array}{c}\text { Realisasi } \\
\text { Penerimaan } \\
\text { (Rp) }\end{array}$ & Persentase \\
\hline 2015 & 2.000 .000 .000 & 2.508 .803 .948 & $125,44 \%$ \\
\hline 2016 & 2.000 .000 .000 & 2.853 .809 .800 & $142,69 \%$ \\
\hline 2017 & 2.000 .000 .000 & 3.469 .803 .840 & $173,49 \%$ \\
\hline 2018 & 37.685 .248 .010 & 4.266 .115 .259 & $11,32 \%$ \\
\hline
\end{tabular}

Sumber: Badan Pengelolaan Keuangan dan Aset Daerah, 2018

Berdasarkan tabel di atas menunjukkan bahwa salah satu penyebab rendahnya persentase penerimaan retribusi jasa angkutan sungai dan penyeberangan terhadap retribusi daerah adalah tingkat target penerimaan retribusi jasa angkutan sungai dan penyeberangan tidak seimbang atau mengalami fluktuasi dengan target yang telah dianggarkan. Tahun 2015-2017 persentase mencapai target dan realisasinya adalah rata-rata lebih dari 100\%, namun pada tahun 2018 persentase tidak tercapai yaitu 11,32\%.

Penetapan target retribusi jasa angkutan sungai dan penyeberangan berdasarkan hasil wawancara yang telah dilakukan dengan Bapak Agus Supriyanto, ATD.MM dan Bapak Ardi mengatakan bahwa penetapan target retribusi yaitu dengan cara increamentalism yang berarti menambah atau mengurangi jumlah rupiah pada item-item anggaran yang sudah ada dengan menggunakan data sebelumnya sebagai dasar untuk menyesuaikan besarnya penambahan atau pengurangan tanpa dilakukan kajian yang mendalam. Penetapan target retribusi daerah juga harus berdasarkan potensi yang ada pada Peraturan Daerah Kota Palembang Nomor 4 Tahun 2012 tentang retribusi jasa usaha. Penetapan target retribusi juga dihitung berdasarkan frekuensi, jenis, dan jangka waktu.

Berdasarkan hasil wawancara maka menurut penulis untuk menentukan target retribusi tidak hanya dari historis, tetapi harus melihat dari aspek ekonomis yaitu dengan melihat dan memperhatikan kemampuan masyarakat dalam membayar retribusi, efisiensi sering dijadikan 
pertimbangan dalam penyusunan anggaran tradisional. Pada konsep ini sering kali pada akhir tahun terjadi kelebihan anggaran yang mengalokasikan kemudian dipaksakan pada aktivitas yang sebenarnya kurang penting untuk dilaksanakan.

Efektifitas yaitu dilihat dari kinerja yang ada apakah sudah optimal atau belum misalnya pengeluaran periode sebelumnya yang dijadikan dasar penyusunan anggaran tahun ini tidak didasarkan atas kebutuhan yang wajar karena dan tersebut akan digunakan oleh Pemerintah Kota Palembang dalam menjalankan perekonomian dan pembangunan baik pada masa sekarang maupun pada masa yang akan datang. Berdasarkan penjelasan di atas terdapat target anggaran penerimaan retribusi jasa angkutan sungai dan penyeberangan yang didapat dari Dishub Kota Palembang yaitu sebagai berikut:

Tabel 3. Target Penerimaan Tahun 2018

\begin{tabular}{|c|c|c|c|c|}
\hline & Jenis Penerimaan & $\begin{array}{l}\text { Target Per } \\
\text { Hari (Rp) }\end{array}$ & $\begin{array}{l}\text { Target Per } \\
\text { Bulan (Rp) }\end{array}$ & $\begin{array}{l}\text { Target Per Tahun } \\
\text { (Rp) }\end{array}$ \\
\hline A & $\begin{array}{l}\text { Retribusi } \\
\text { Pelayanan Jasa } \\
\text { Kepelabuhan/ } \\
\text { UPTD }\end{array}$ & & & \\
\hline 1 & $\begin{array}{l}\text { UPTD Tangga } \\
\text { Buntung }\end{array}$ & 100.000 & 3.000 .000 & 36.000 .000 \\
\hline 2 & UPTD 16 Ilir & 500.000 & 15.000 .000 & 180.000 .000 \\
\hline 3 & UPTD Sungai Lais & 300.000 & 9.000 .000 & 108.000 .000 \\
\hline 4 & UPTD Jakabaring & 100.000 & 3.000 .000 & 36.000 .000 \\
\hline 5 & $\begin{array}{l}\text { Pelabuhan } \\
\text { Penyeberangan }\end{array}$ & 210.000 & 6.300 .000 & 75.600 .000 \\
\hline 6 & $\begin{array}{l}\text { Setoran PT. } \\
\text { Pelindo II }\end{array}$ & 4.195 .000 & 125.850 .000 & 1.510 .200 .000 \\
\hline 7 & $\begin{array}{l}\text { Sewa } \\
\text { Lahan/Ruangan }\end{array}$ & 25.000 & 750.000 & 9.000 .000 \\
\hline 8 & $\begin{array}{l}\text { Sewa Perairan } \\
\text { Pelabuhan }\end{array}$ & 40.000 & 1.200 .000 & 14.400 .000 \\
\hline 9 & $\begin{array}{l}\text { Jasa Rambu dan } \\
\text { Wajib Pengawalan }\end{array}$ & 99.125.689 & 2.973 .770 .675 & 35.685 .248 .101 \\
\hline & JUMLAH (A) & 104.595 .689 & 3.137 .870 .675 & 35.654 .448 .101 \\
\hline B & $\begin{array}{l}\text { Retribusi } \\
\text { Pelayanan } \\
\text { Penyeberangan } \\
\text { Orang } \\
\end{array}$ & & & \\
\hline 1 & $\begin{array}{l}\text { Serta Pengujian } \\
\text { Kendaraan di } \\
\text { Atas Air }\end{array}$ & 20.000 & 600.000 & 7.200 .000 \\
\hline 2 & Sewa Kapal & 65.556 & 1.966 .680 & 23.600 .000 \\
\hline
\end{tabular}

Sumber: Dinas Perhubungan, 2018

Berdasarkan data target penerimaan retribusi jasa angkutan sungai dan penyeberangan Kota Palembang pada tabel di atas terlihat bahwa penerimaan retribusi jasa angkutan sungai dan penyeberangan mengalami fluktuasi dengan target yang dianggarkan di tahun sebelumnya. Permasalahan di retribusi jasa angkutan sungai dan penyeberangan yaitu jasa rambu dan wajib pengawalan belum dapat diterapkan sepenuhnya oleh pemerintah hal ini dikarenakan fasilitas infrastruktur wilayah perairan belum memadai.

Pembangunan di sektor perairan sangat penting maka dari itu petugas menambahkan target anggaran untuk jasa rambu dan wajib pengawalan agar fasilitas infrastruktur di perairan dapat berjalan dengan baik. Jika fasilitas di perairan sudah ada maka akan mempermudah masyarakat untuk melintasi aliran sungai Musi karena sudah adanya pencahayaan di malam hari dan tidak terjadinya kecelakaan sehingga kapal atau perahu yang melintas pun tidak menabrak tiang jembatan jika melintasi aliran sungai Musi. Tetapi penambahan target anggaran jasa rambu dan wajib pengawalan tidak bisa dijalankan sepenuhnya dikarenakan dasar hukum yang kurang kuat.

Berdasarkan hasil wawancara yang telah dilakukan dengan Bapak Agus Supriyanto, ATD.MM dan Bapak Ardi mengatakan bahwa terjadi fluktuasi antara target penerimaan dengan presentase yang didapatkan dikarenakan tidak berjalannya target penerimaan yang dianggarkan. Penarikan retribusi juga merujuk pada amanat Peraturan Daerah (Perda) Kota Palembang Nomor 17 Tahun 2011 tentang retribusi jasa usaha penyelenggaraan transportasi. Perda ini mengatur dilaksanakannya penarikan retribusi jasa angkutan sungai Musi yang melintasi Kota Palembang.

Pemerintah Kota juga melakukan pemungutan untuk retribusi jasa angkutan sungai dengan menambah target penerimaan di jasa rambu dan wajib pengawalan diharapkan mampu untuk menambah peningkatan Pendapatan Asli Daerah. Namun penambahan target yang diharapkan mampu meningkatkan Pendapatan Asli Daerah tetapi malah mengalami penurunan yaitu $11,32 \%$ berbeda jauh dengan tahun sebelumnya yang bisa mencapai target anggaran dengan presentase $100 \%$ lebih. Hal ini dikarenakan adanya kendala yaitu dasar hukum yang kurang kuat sehingga persentasenya tidak mencapai target padahal penarikan retribusi jasa angkut akan diambil dari batu bara sebesar Rp35.000.000.000,-. Perusahaan akan membayar retribusi dengan jumlah tersebut jika fasilitas infrastruktur yang memadai dari pemerintah.

Kewenangan yang terbatas dikarenakan adanya aturan yang dibuat Pemerintah Kota yaitu Peraturan Walikota Palembang Nomor 35 Tahun 2017 yang bertentangan dengan aturan di atas sehingga tidak bisa dilaksanakan. Aturan di atas yaitu Undang-Undang, Peraturan Pemerintah, Peraturan Menteri, Peraturan Daerah, dan Perwali. Perwali ini akan ditingkatkan menjadi Perda namun tidak bisa karena bertentangan harus sesuai dengan Undang-Undang, Peraturan Pemerintah, dan Peraturan Menteri sehingga tidak bisa dilaksanakan sedangkan Pemerintah Kota mengharapkan dari target penerimaan ini untuk meningkatkan Pendapatan Asli Daerah.

Berdasarkan hasil wawancara tersebut, maka penulis menarik kesimpulan bahwa Pemerintah Kota Palembang seharusnya dalam penambahan 
target penerimaan harus diperkuat dasar hukum terlebih dahulu dan menambahkan fasilitas infrastruktur yang memadai untuk wilayah perairan. Perusahaan dan penyeberangan orang atau barang dapat membayar dengan teratur sehingga bisa mencapai target yang diharapkan agar pemerintah mampu meningkatkan Pendapatan Asli Daerah.

b. Analisis belum dimilikinya database atau data dasar mengenai sumber penerimaan

Database atau data dasar merupakan kumpulan informasi yang disimpan di dalam komputer secara sistematik untuk memperoleh informasi dari data dasar tersebut. Berdasarkan hasil wawancara dengan Bapak Agus Supriyanto, ATD.MM dan Bapak Ardi yang mengatakan bahwa pada retribusi jasa angkutan sungai dan penyeberangan telah memiliki database atau data dasar mengenai sumber penerimaan secara akurat dan gambaran menyeluruh mengenai data-data potensi pada retribusi jasa angkutan sungai dan penyeberangan. Jika data-data mengenai retribusi telah terdata secara baik di database dengan mudah Dishub Kota Palembang dapat mengetahui berapa besar potensi yang dimilki dan potensi yang dapat digali atau dikembangkan serta dikelola dari setiap retribusi yang dimilki.

Berdasarkan dari wawancara tesebut maka penulis menarik kesimpulan bahwa database itu sangat penting untuk mengetahui dan menyimpan data dasar sumber penerimaan retribusinya dan mempermudah petugas untuk melakukan pemungutan retribusi jasa angkutan sungai dan penyeberangan. Pemerintah harus mempunyai dan mengembangkan program-program baru agar lebih mempermudah proses pemungutan tersebut.

\subsubsection{Masih Tingginya Tingkat Kebocoran atau Kelolosan}

a. Analisis belum efektifitasnya pemberlakuan sanksi

Pemberlakuan sanksi yang mengatur tentang retribusi jasa usaha di peraturan yang telah dibuat oleh Walikota Palembang yang tertera di Perda Kota Palembang Nomor 17 Tahun 2011 tentang retribusi jasa usaha penyelenggara transportasi. Pemungutan retribusi penyeberangan ketek juga kadang ada yang tidak membayar retribusi, tetapi ada kesulitan juga mengambil retribusi penyeberangan terutama ketek karena tidak tercapainya standar. Berdasarkan peraturan yang terdapat di Perda Kota Palembang Nomor 17 Tahun 2011 tentang jasa usaha penyelenggaraan transportasi terdapat tarif penarikan retribusi yang dilakukan petugas untuk melakukan pemungutan yaitu sebagai berikut:
Tabel 4. Jasa Kepelabuhan Sungai dan Danau

\begin{tabular}{|c|l|r|c|}
\hline No & $\begin{array}{l}\text { Retribusi } \\
\text { Tambat/Labuh } \\
\text { Kapal Setiap } \\
\text { Dermaga }\end{array}$ & $\begin{array}{c}\text { Besarnya } \\
\text { Tarif } \\
(\text { Rp) }\end{array}$ & Keterangan \\
\hline 1 & $\begin{array}{l}\text { Tongkang } \\
\text { Besi/Gandeng }\end{array}$ & 15.000 & Sekali Tambat \\
\hline 2 & $\begin{array}{l}\text { Jukung, Gandeng, } \\
\text { Tongkang Kayu }\end{array}$ & 10.000 & Sekali Tambat \\
\hline 3 & Ketek Barang & 2.000 & Sekali Tambat \\
\hline 4 & Ketek Penumpang & 1.500 & Sekali Tambat \\
\hline 5 & Speed Boat <85 PK & 5.000 & Sekali Tambat \\
\hline 6 & $\begin{array}{l}\text { Speed Boat } \\
85><200 \text { PK }\end{array}$ & 10.000 & Sekali Tambat \\
\hline 7 & Speed Boat $>200$ PK & 20.000 & Sekali Tambat \\
\hline 8 & Kapal $<20$ GT & 20.000 & Sekali Tambat \\
\hline 9 & Kapal 20><50 GT & 25.000 & Sekali Tambat \\
\hline 10 & Kapal 50><100 GT & 30.000 & Sekali Tambat \\
\hline 11 & Kapal $>100$ GT & 75.000 & Sekali Tambat \\
\hline
\end{tabular}

Sumber: Dinas Perhubungan, 2018

Berdasarkan tabel tarif penarikan retribusi di atas menujukkan bahwa besarnya tarif retribusi yang harus dibayar oleh wajib retribusi disesuaikan dengan kondisi di lapangan. Terutama untuk retribusi jasa kepelabuhan pada UPTD dan jasa pelabuhan ke perusahaan, untuk penyeberangan orang berkisar antara Rp2.000 untuk ketek/perahu, dan Rp15.000 untuk tongkang per hari. Perda Kota Palembang Nomor 17 Tahun 2011 juga memberikan sanksi jika tidak membayar retribusi yang sudah ditetapkan dengan tepat waktu dan kurang bayar yaitu dikenakan sanksi administrasi berupa bunga $2 \%$ setiap bulan atau potongan setiap pembayaran dipotong $2 \%$ untuk pembayaran retribusi yang terutang. Jika tidak melakukan pembayaran maka akan diancam pidana dengan kurungan paling lama 3 bulan atau pidana denda paling banyak 3 kali jumlah retribusi terutang.

Berdasarkan wawancara yang telah dilakukan dengan Bapak Agus Supriyanto, ATD.MM dan Bapak Ardi mengatakan bahwa ketegasan para petugas di lapangan sangat diperlukan dalam pemberlakuan sanksi tetapi di retribusi jasa angkutan dan penyeberangan yaitu dengan melakukan penyetoran retribusi secara langsung. Hasil dari retribusi yang telah terkumpul kemudian diserahkan oleh petugas pemungut retribusi kepada bendahara I dari UPTD untuk pendapatan retribusi, bendahara II dari pelayanan kepelabuhan perusahaan untuk pendapatan retribusi, dan bendahara III dari pelayanan jasa perorangan untuk pendapatan retribusi, kemudian bendahara I, II, dan III menyetorkan pendapatan retribusi pada bendahara Dishub Kota Palembang.

Berdasarakan dari wawancara maka menurut penulis, untuk dapat meningkatkan pengenaan sanksi, maka setiap petugas harus meningkatkan penyuluhan kepada setiap masyarakat yang membayar retribusi atau melalui himbauan secara tertulis yang dapat menumbuhkan kesadaran masyarakat dalam membayar retribusi. 
b. Analisis Kurangnya Sarana dan Prasarana di Lapangan

Dinas perhubungan untuk retribusi jasa angkutan sungai dan penyeberangan, sarana dan prasarana merupakan faktor penunjang dalam peningkatan Pendapatan Asli Daerah (PAD). Terdapat empat dermaga dan satu pelabuhan, yaitu dermaga Tangga Buntung, dermaga Sungai Lais, dermaga 16 Ilir, dermaga Jakabaring, dan pelabuhan 35 Ilir. Meskipun banyak dermaga tetapi tidak bisa mencapai target karena kewenangan terbatas dan fasilitas di lapangan yang belum memadai, misalnya masyarakat sekarang lebih banyak menggunakan kendaraan pribadi seperti roda dua atau roda empat dan masyarakat jarang yang mau menyeberang menggunakan ketek apalagi fasilitas di perairan juga tidak memadai banyak mengalami kecelakaan sehingga membuat masyakat takut untuk menyeberang atau menggunakan jasa angkut lewat perairan.

Berdasarkan hasil wawancara yang telah dilakukan dengan Bapak Agus Supriyanto, ATD.MM dan Bapak Ardi yang mengatakan bahwa pemerintah sudah menambahkan target penerimaan yaitu jasa rambu dan wajib pengawalan tetapi fasilitas di wilayah perairan tidak memadai karena dasar hukumnya kurang kuat dan perusahaan yang membayar retribusi juga menginginkan fasilitas sarana dan prasarana di lapangan dilengkapi.

Berdasarkan hasil wawancara, maka penulis menarik kesimpulan bahwa sarana dan prasarana di lapangan untuk retribusi jasa angkutan sungai dan penyeberangan belum lengkap seperti fasilitas di perairan yang belum memadai dikarenakan peraturan daerah yang telah ditetapkan oleh pemerintah kota tetapi dasar hukum yang kurang kuat yaitu Peraturan Walikota Palembang Nomor 35 Tahun 2017 yang bertentangan dengan aturan di atas sehingga tidak bisa dilaksanakan dan petugas tidak bisa melakukan pemungutan retribusi secara keseluruhan.

\subsubsection{Analisis Belum Primanya Layanan} Terbatasnya Sumber Daya Manusia atau Petugas Pelaksana Lapangan

Pelayanan merupakan salah satu usaha yang harus dikedepankan untuk sementara ini pelayanan yang diberikan oleh dinas perhubungan sudah baik. Kualitas pelayanan sangat penting agar penerimaan retribusi dapat mencapai target. Salah satu pelayanan yang baik adalah Sumber Daya Manusia (SDM), yang di mana SDM mempunyai peran yang penting dalam peningkatan penerimaan retribusi daerah. Sumber Daya Manusia di sini yaitu aparat pemungutan retribusi yang berada di lapangan. Aparat pemungut retribusi hendaknya memiliki kemampuan atau pengetahuan yang mendalam mengenai permasalahan tugas yang mereka ambil yaitu dalam hal pemungutan retribusi daerah, sehingga dengan kemampuan dan pengetahuan yang dimiliki aparat pemungut retribusi akan dapat melaksanakan tugas yang mereka ambil dengan sebaik mungkin.

Berdasarkan hasil wawancara yang telah dilakukan dengan Bapak Agus Supriyanto, ATD.MM dan Bapak Ardi mengatakan bahwa pada Dishub Kota Palembang pemungutan retribusi jasa angkutan tidak bisa dijalankan sepenuhnya dikarenakan dasar hukum yang kurang kuat dan terbentuknya aturan bukannya tidak mau memberikan pelayanan. Sungai yang beroperasi pun yaitu sungai kecil dan pemerintah kota tidak ada kewenangan sepenuhnya yang mempunyai kewenangan sepenuhnya yaitu SOP Nusa Bandara bisa terjun langsung.

Kendalanya adalah layanan yang terbatas atau sumber daya manusia, dasar hukum yang tidak kuat karena adanya aturan yang dibuat oleh Pemerintah Kota Palembang berupa Perwali Nomor 35 Tahun 2017 tentang pengawalan yang bertentangan dengan aturan yang diatas sehingga tidak bisa dilaksanakan. Sebenarnya layanan prima dan sumber daya manusia semua sudah siap tetapi aturan yang bertentangan jadi tidak bisa dijalankan sepenuhnya. Salah satu terobosan yang dilakukan retribusi jasa angkutan sungai dan penyeberangan yaitu pengajuan ke DPR namun belum selesai dan dilakukan rapat kembali dengan DPR namun masih belum ada hasilnya.

Berdasarkan dari wawancara maka kesimpulannya bahwa pemerintah kota harus melakukan rapat pengajuan ke DPR supaya petugas yang beroperasi bisa menjalankan pemungutan retribusi tanpa ada kendala dan peraturan walikota tidak lagi bertentangan dengan aturan yang di atas. Petugas mampu memberikan pelayanan untuk perusahaan dan setiap UPTD sehingga tidak menyebabkan pelayanan yang terbatas.

Berdasarkan pembahasan dari beberapa faktor maka dapat disimpulkan bahwa kendala yang dihadapi dinas perhubungan yaitu dasar hukum yang kurang kuat dan kewenangan yang terbatas. Dasar hukum yang kurang kuat dikarenakan adanya aturan yang dibuat Pemerintah Kota yaitu Peraturan Walikota Palembang Nomor 35 Tahun 2017 tentang pengawalan. Peraturan inilah yang menjadi dasar hukum yang kurang kuat karena bertentangan dengan aturan di atas yaitu Undang-undang, Peraturan Menteri, Peraturan Pemerintah, Peraturan Daerah, dan Peraturan Walikota.

Aparat petugas di lapangan tidak bisa melakukan pemungutan retribusi menyeluruh dikarenakan semua peraturan sudah ditetapkan oleh Pemerintah Kota sehingga penarikan yang diambil sangat kecil dan kewenangan yang terbatas. Padahal penarikan retribusi terbesar yaitu dari perusahaan namun karena kewenangan 
yang terbatas sehingga petugas tidak bisa menjalankan penarikan retribusi tersebut tanpa ada aturan dari Pemerintah Kota.

Petugas tidak bisa melakukan penarikan untuk retribusi jasa angkutan sungai dan penyeberangan secara keseluruhan dikarenakan fasilitas di perairan yang tidak memadai dan perusahaan tidak mau membayar retribusi jika fasilitas dari pemerintah tidak ada. Jika dasar hukum sudah kuat dan Peraturan Walikota sudah ditingkatkan menjadi Peraturan Daerah maka petugas di lapangan yang melakukan penarikan retribusi pun tidak ada kewenangan yang terbatas lagi.

Pemerintah melakukan rapat dengan DPR dan melakukan persetujuan atau kerjasama dengan perusahaan agar petugas pemungutan retribusi tidak ada kendala lagi sehingga jasa rambu dan wajib pengawalan dapat dijalankan. Fasilitas infrastruktur di wilayah perairan juga memadai maka dapat meningkatkan Pendapatan Asli Daerah seperti yang diharapkan Pemerintah Kota Palembang.

\section{KESIMPULAN DAN SARAN 5.1 Kesimpulan}

Berdasarkan pembahasan penelitian yang telah dipaparkan sebelumnya maka kesimpulan yang dapat dari hasil penelitian bahwa penetapan target retribusi yaitu dengan cara increamentalism yang berarti menambah atau mengurangi jumlah rupiah pada item-item anggaran yang sudah ada dengan menggunakan data sebelumnya sebagai dasar untuk menyesuaikan besarnya penambahan atau pengurangan tanpa dilakukan kajian yang mendalam. Penetapan target retribusi daerah juga harus berdasarkan potensi yang ada yaitu Peraturan Daerah Kota Palembang Nomor 4 Tahun 2012 tentang retribusi jasa usaha. Penetapan target retribusi juga dihitung berdasarkan frekuensi, jenis, dan jangka waktu.

Peraturan Walikota Palembang Nomor 35 Tahun 2017 sudah dijalankan tetapi Pemerintah Kota ingin meningkatkannya menjadi Peraturan Daerah namun bertentangan dengan UndangUndang, Peraturan Menteri, dan Peraturan Pemerintah sedangkan Pemerintah Kota Palembang mengharapkan ini untuk meningkatkan Pendapatan Asli Daerah. Jika Pemerintah Kota Palembang sudah meningkatkan Peraturan Walikota Palembang ini menjadi Peraturan Daerah Kota Palembang maka penarikan retribusi jasa angkutan sungai sudah bisa diterapkan dan pendapatan Pemerintah Kota pun meningkat.

Pemungutan retribusinya juga mengalami kebocoran atau kelolosan karena belum efektifitasnya pemberlakuan sanksi dan kurangnya sarana dan prasarana di lapangan. Petugas pemungutan retribusi bukan tidak mau memberikan pelayanan dan sumber daya manusia juga tetapi karena aturan yang bertentangan sehingga membuat petugas tidak bisa menjalankan penarikan secara menyeluruh. Petugas bergerak dengan aturan yang telah ditetapkan oleh Pemerintah Kota Palembang sehingga kewenangannya terbatas.

\subsection{Saran}

Berdasarkan simpulan yang diuraikan, maka saran yang penulis dapat berikan untuk mengatasi faktor tidak tercapainya realisasi penerimaan retribusi jasa angkutan sungai dan penyeberangan pada Dishub Kota Palembang sebagai berikut:

a. Pemerintah dan petugas dinas perhubungan harus melakukan rapat dengan DPR agar secepatnya dapat diselesaikan masalah yang dihadapi sehingga dasar hukumnya menjadi kuat dan mempermudah petugas di lapangan melakukan pemungutan retribusi tersebut.

b. Pemerintah juga harus melakukan rapat dengan perusahaan untuk membahas tentang kerjasama dan pemerintah harus memenuhi apa yang diinginkan perusahaan jika sudah membayar retribusi.

c. Sarana dan prasarana seperti fasilitas infrastruktur lebih dilengkapi sehingga masyarakat yang melintasi aliran sungai Musi menjadi lebih mudah.

\section{IMPLIKASI DAN KETERBATASAN}

Penelitian ini diharapkan dapat memberikan manfaat di kalangan akademisi khususnya praktisi terutama pemerintah dalam hal ini Dishub Kota Palembang dalam memberikan kebijakankebijakan bagi kepentingan publik. Kebermanfaatan hasil penelitian ini akan lebih baik dan luas lagi apabila para praktisi terkait ke depannya dapat lebih kooperatif lagi dalam memberikan informasi-informasi yang mendukung penelitian-penelitian yang dilakukan para akademisi yang bertujuan untuk meningkatkan kualitas layanan publik.

Penelitian ini masih terdapat banyak kekurangan, hubungan kerja sama antara para peneliti dan pihak-pihak terkait dalam penelitian ini yang sesungguhnya sangat penting namun jika tanpa adanya keterbukaan terutama akan datadata yang dibutuhkan penulis untuk menjawab permasalahan-permasalahan yang terjadi. Ke depan diharapkan adanya keterbukaan pihak pemerintah mengenai hal-hal yang menunjang penelitian-penelitian berikutnya yang bertujuan membantu dalam menganalisa permasalahanpermasalahan yang ada, sehingga penelitian terkait akan lebih bermanfaat secara luas bagi akademisi, praktisi, dan masyarakat pada umumnya. 


\section{REFERENSI}

Gumilar, I. S. P. (2016). Analisis efektivitas dan kontribusi penerimaan retribusi jasa usaha terhadap pendapatan asli daerah. Jurnal Aplikasi Manajemen, 14(3), 419-431.

Halim, A. (2006). Akuntansi keuangan daerah. Jakarta: Salemba Empat.

Kurniawan, A. (2014). Metode riset untuk ekonomi dan bisnis. Bandung: Alfabeta.

Mega, E., \& Elim, I. (2016). Analisis efektivitas penerimaan retribusi daerah dan kontribusinya terhadap peningkatan pendapatan asli daerah (pad) di provinsi Sulawesi Utara. Jurnal Riset Ekonomi, Manajemen, Bisnis, dan Akuntansi, 4(1), 889-897.

Pekei, B. (2016). Konsep dan analisis efektivitas pengelolaan keuangan daerah di era otonomi. Cetakan Pertama. Jakarta Pusat: Taushia.

Peraturan Daerah Kota Paembang Nomor 4 Tahun 2012 dirubah oleh Peraturan kedua atas Peraturan Daerah Kota Palembang Nomor 10 Tahun 2008 Tentang Pembentukan, Susunan Organisasi, dan Tata Kerja Lembaga Tehnis Daerah Kota Palembang.

Peraturan Daerah Kota Palembang Nomor 17 Tahun 2011 tentang Retribusi Jasa Usaha Penyelenggaraan Transportasi.

Putra, W. (2018). Tata kelola ekonomi keuangan daerah. Cetakan Pertama. Jakarta: PT. Raja Grafindo Persada.

Putra, B. F., Atmanto, D., \& Nuzula, N. F. (2014). Analisis efektivitas penerimaan dan kontribusi retribusi daerah terhadap pendapatan asli daerah Kota Blitar. Jurnal Administrasi Bisnis, 10(1), 1-9.

Siahaan, M. P. (2005). Pajak daerah \& retribusi daerah. Jakarta: Raja Grafindo Persada.

Siregar, R. A. (2017). Pemkot Palembang akan tarik retribusi kapal yang melintas di Musi. Diakses tanggal 06 Mei 2019, dari https://news.detik.com/ berita/d-3494013/pemkot-palembang-akan-tarikretribusi-kapal-yang-melintas-di-musi.

Sri, M., \& Kasasih, D. (2017). Analisis kontribusi dan efektivitas penerimaan retribusi pelayanan pasar terhadap pendapatan asli daerah kota Palembang. Jurnal Kompetitif, 6(1), 93-94.

Sudaryo, Y., Sjarif, D., \& Sofiati, N. A. (2017). Keuangan di era otonomi daerah. Yogyakarta: Penerbit Andi Offset.

Sujarweni, V. W. (2015). Metodologi penelitian bisnis \& ekonomi. Cetakan Pertama. Yogyakarta: Pustaka Baru Press.

Sujarweni, V. W. (2016). Akuntansi sektor publik teori, konsep, aplikasi. Cetakan Pertama. Yogyakarta: Pustaka Baru Press.

Susilo, \& Halim. (2002). Upaya peningkatan pendapatan asli daerah dalam rangka pelaksanaan otonomi daerah (studi pada Pemerintah Kota Malang). Jurnal Ekonomi dan Manajemen, 3(2), 4956.

Yuliastuti, I. A. N., \& Dewi, N. L. P. S. (2017). Analisis efektivitas dan kontribusi retribusi daerah terhadap pendapatan asli daerah (pad) kota Denpasar. Jurnal Riset Akuntansi, 7(1), 91-102. 